\title{
The Biotechnological Potential of Secondary Metabolites from Marine Bacteria
}

\author{
Boris Andryukov ${ }^{1, *}$, Valery Mikhailov ${ }^{2}$ and Nataly Besednova ${ }^{1}$ \\ 1 G.P. Somov Research Institute of Epidemiology and Microbiology, 690087 Vladivostok, Russia; \\ besednoff_lev@mail.ru \\ 2 G.B. Elyakov Pacific Institute of Bioorganic Chemistry, Far Eastern Branch, Russian Academy of Sciences, \\ 690022 Vladivostok, Russia; vvmikhailov@inbox.ru \\ * Correspondence: andrukov_bg@mail.ru; Tel.: +7-9242-3046-47
}

Received: 4 May 2019; Accepted: 29 May 2019; Published: 3 June 2019

check for updates

\begin{abstract}
Marine habitats are a rich source of molecules of biological interest. In particular, marine bacteria attract attention with their ability to synthesize structurally diverse classes of bioactive secondary metabolites with high biotechnological potential. The last decades were marked by numerous discoveries of biomolecules of bacterial symbionts, which have long been considered metabolites of marine animals. Many compounds isolated from marine bacteria are unique in their structure and biological activity. Their study has made a significant contribution to the discovery and production of new natural antimicrobial agents. Identifying the mechanisms and potential of this type of metabolite production in marine bacteria has become one of the noteworthy trends in modern biotechnology. This path has become not only one of the most promising approaches to the development of new antibiotics, but also a potential target for controlling the viability of pathogenic bacteria.
\end{abstract}

Keywords: biotechnologies; marine bacteria; secondary metabolites; non-ribosomal biosynthesis; antibacterial strategies

\section{Introduction}

Recently, marine microorganisms have attracted much attention from researchers as sources of new biologically active substances. This is due to the huge variety of living conditions of marine microorganisms and the lack of sufficient knowledge about them [1,2].

A number of marine bacteria represent a great deal of biotechnological interest, for example, for bioremediation, production of biosurfactants and the biochemistry of "psychrophilic" enzymes synthesized by low-temperature-adapted microorganisms [3-5]. These substances have high potential in relation to biotechnological applications in the detergent and food industry, the production of chemical reagents and medicines. In addition, a large number of new antibiotics have been identified from marine bacteria $[2,4,6]$.

Despite the significant advances in medicine, diagnostics and treatment of infectious diseases, pathogenic microorganisms still pose a serious threat to the world's human population. Their impact is significant, both in developing countries-due to their limited access to medicines, and in developed countries-where uncontrolled administration of antibiotics has led to a wide distribution of multi-resistant bacteria. The strategy of creating new synthetic antibiotics by modifying existing natural ones has not proven effective enough_pathogenic microorganisms become resistant to new drugs after their first trials. The world community, represented by the World Health Organization, raises reasonable concern for the future of mankind and encourages searching for novel antimicrobial agents that can become an alternative to modern antibiotics [1,2]. A number of promising strategies 
for the search for new antibiotic drugs are associated with the use of products of metabolism of marine bacteria.

The bacterial metagenome contributes to the production of primary metabolites and transforms small protein molecules into secondary metabolites, also referred to as "specialized metabolites". They play an important role in cell growth, signal transmission, search for nutrients, intra- and interspecies communication and competition, and are, therefore, of increased interest to researchers considering them as potential alternatives to traditional antibiotics. Of particular importance is the study of antibacterial activity of antimicrobial peptides, which are secondary metabolites of marine microorganisms [3].

Humankind has learned to use resources of the World Ocean, which covers more than $70 \%$ of the earth's surface, since long ago. Despite this fact, marine bacteria aroused researchers' interest only in the middle of the 20th century, although some studies of the biological activity of metabolites of these microorganisms were published as early as in the late 19th century. It was found that the marine environment, including bottom sediments, represents a giant pool of microbial biodiversity, numbering up to approximately $3.67 \times 10^{30}$ microorganisms [4].

Even the few studies in recent decades have shown that the marine ecosystem, with its unique diversity of habitats and abundant biota, is an inexhaustible resource of biologically active natural chemical substances. Numerous compounds with noteworthy pharmaceutical activities, which can become sources of novel therapeutic agents, have been described from marine organisms over recent decades [5-7]. In particular, antibacterial substances that are secondary metabolites of marine bacteria attract much of researchers' attention because of their high antibacterial potential.

These substances are the subject of extensive research conducted in marine microbiology and chemistry of marine natural compounds, which is intensively developing nowadays. Because of their unique properties, they have become one of the priorities for modern marine biotechnology.

The aim of this review is to compile modern literary data on the structure and antibiotic activity of secondary metabolites of marine bacteria and their biotechnological potential. About $70 \%$ of the identified secondary metabolites of marine bacteria are represented by non-ribosomal peptides (NRP) or a mixed polyketide-non-ribosomal family of peptides with diverse biological activity [8-10]. Therefore, this review focuses on this group of metabolites, the synthesis of which, unlike other proteins, does not depend on the ribosomal mechanism.

The search for data sources was carried out in the Cochrane Library database (at Wiley Online Library), EMBASE (EMBASE.com), PubMed, PubMed Central, EMBASE and MEDLINE, integrated on the platform of Elsevier, CINAHL, Web of Science and Health Economic Evaluations. Because of the great scientific attention to the issue of "antibacterial metabolites" and "antibacterial peptides", the strategy of sampling was limited to the search for scientific reviews with the following word combinations contained in the title, abstract and topical catalogs: "marine bacteria and secondary metabolites", "marine bacteria and antibacterial peptides" and "marine bacteria and non-ribosomal biosynthesis". The depth of search was 2007-2019.

\section{Bacterial Metabolites}

Bacteria live in the environment of transmitted and received chemical signals, with signal molecules being metabolites, i.e., terminal products of cellular metabolism. The latter is a combination of two opposite but interrelated processes - energetic (catabolism) and constructive (anabolism). This is a continuous and multi-component biochemical process that occurs in every bacterial cell throughout its lifecycle $[8,10]$.

Terminal products of metabolism, being small peptide molecules, are used as substrates for biochemical reactions or are utilized by microorganisms to support their life processes. This is a wide range of molecules, extremely diverse in their structures and functions, with their registered number exceeding 25,000 , which accounts for less than $2 \%$ of the total number of natural metabolites of microorganisms not yet available for research [9-11]. 
Depending on the functional properties and biosynthesis mechanisms, metabolites are divided into primary and secondary. Primary metabolites serve as the main energy source for providing various biochemical reactions and performing physiological functions to support life processes of bacterial cells, such as growth and development. Secondary metabolites are organic compounds with a complex chemical structure and a variety of physiological functions. They are required to implement the survival strategies of bacteria in adverse conditions, acting as mediators with the external environment and means of intercellular communication (Table 1).

Table 1. Key biochemical and physiological properties of primary and secondary metabolites of bacteria [8].

\begin{tabular}{ll}
\hline \multicolumn{1}{c}{ Primary Metabolites } & \multicolumn{1}{c}{ Secondary Metabolites } \\
\hline Small-sized molecules & Small-sized molecules \\
\hline $\begin{array}{l}\text { Produce several intermediate and } \\
\text { terminal product }\end{array}$ & $\begin{array}{l}\text { Participate in the synthesis of new compounds } \\
\text { and a multitude of molecules }\end{array}$ \\
\hline $\begin{array}{l}\text { Terminal products involved in the synthesis of } \\
\text { macromolecules, coenzyme }\end{array}$ & Not vitally important for cell growth \\
\hline Important for cell growth and viability & Have unusual chemical structures \\
\hline Have a simple chemical structure & $\begin{array}{l}\text { Terminal products are used as } \\
\text { antibacterial agents }\end{array}$ \\
\hline Synthesized during the lag phase of bacterial growth & $\begin{array}{l}\text { Synthesized at the beginning of stationary phase } \\
\text { of bacterial growth }\end{array}$ \\
\hline Used in food and feed industry & $\begin{array}{l}\text { Used in medicine, cosmetics and agriculture as } \\
\text { preservatives }\end{array}$ \\
\hline Provide energy reserve for communication of cells & $\begin{array}{l}\text { Protect bacteria during the period of adverse } \\
\text { conditions }\end{array}$ \\
\hline $\begin{array}{l}\text { Main source of energy for cellular metabolism and } \\
\text { life support }\end{array}$ & $\begin{array}{l}\text { Participate in intercellular communication, cell } \\
\text { protection and competition for food and space }\end{array}$ \\
\hline
\end{tabular}

Since this review is focused on the bioactive properties of secondary metabolites of marine bacteria, the main emphasis will be on these complex molecules.

\section{Secondary Metabolites of Bacteria}

Marine microorganisms are a significant source for the discovery and development of new biologically active compounds because of their rich biodiversity and genetic ability to produce unique secondary metabolites.

This group of metabolites is an essential component supporting life processes of marine bacteria, fungi, archaea and other microorganisms, which are rich sources of these compounds. Substances with various biological properties, including antibacterial, antifungal, antiviral and antiproliferative agents, exotoxins, metal carriers, hormones, immunomodulators, pigments and enzyme inhibitors, have been found among these complex biomolecules synthesized by marine prokaryotes [8-10].

Many of these compounds, exhibiting high biological activity, play an important role in life functions of bacteria and are widely used in pharmacology, cosmetics, food industry and agriculture. Nevertheless, some bacteria (such as Clostridium botulinum, Vibrio cholerae, Escherichia coli and Yersinia sp.) synthesize exotoxins, which are secondary metabolites and cause diseases in humans [10].

In particular, the secondary metabolites of marine bacteria have proven to be a rich source of natural products with a new structure and excellent antibiotic activity. For example, among actinomycetes, which represent the most important source of biologically active natural products for clinical or pharmaceutical use, more than 5000 antibiotics related to secondary metabolites have been identified [8], including traditional antibiotics discovered in the 1950s and 1960s and also antibiotics. According to forecasts, these bacteria can produce up to 150,000 different chemical antimicrobial agents $[8,9]$. 
Modern science considers secondary metabolites as a group of low-molecular-weight, structurally diverse and complex bioactive compounds. It has been found that the active stage of synthesis of these molecules in microorganisms occurs at the end of the exponential and the beginning of the stationary phases of their growth (Figure 1A). Their production is induced by depletion of nutrients and adverse habitat conditions; the genes responsible for the biosynthesis of secondary metabolites are grouped together in a small number of clusters [10,12].

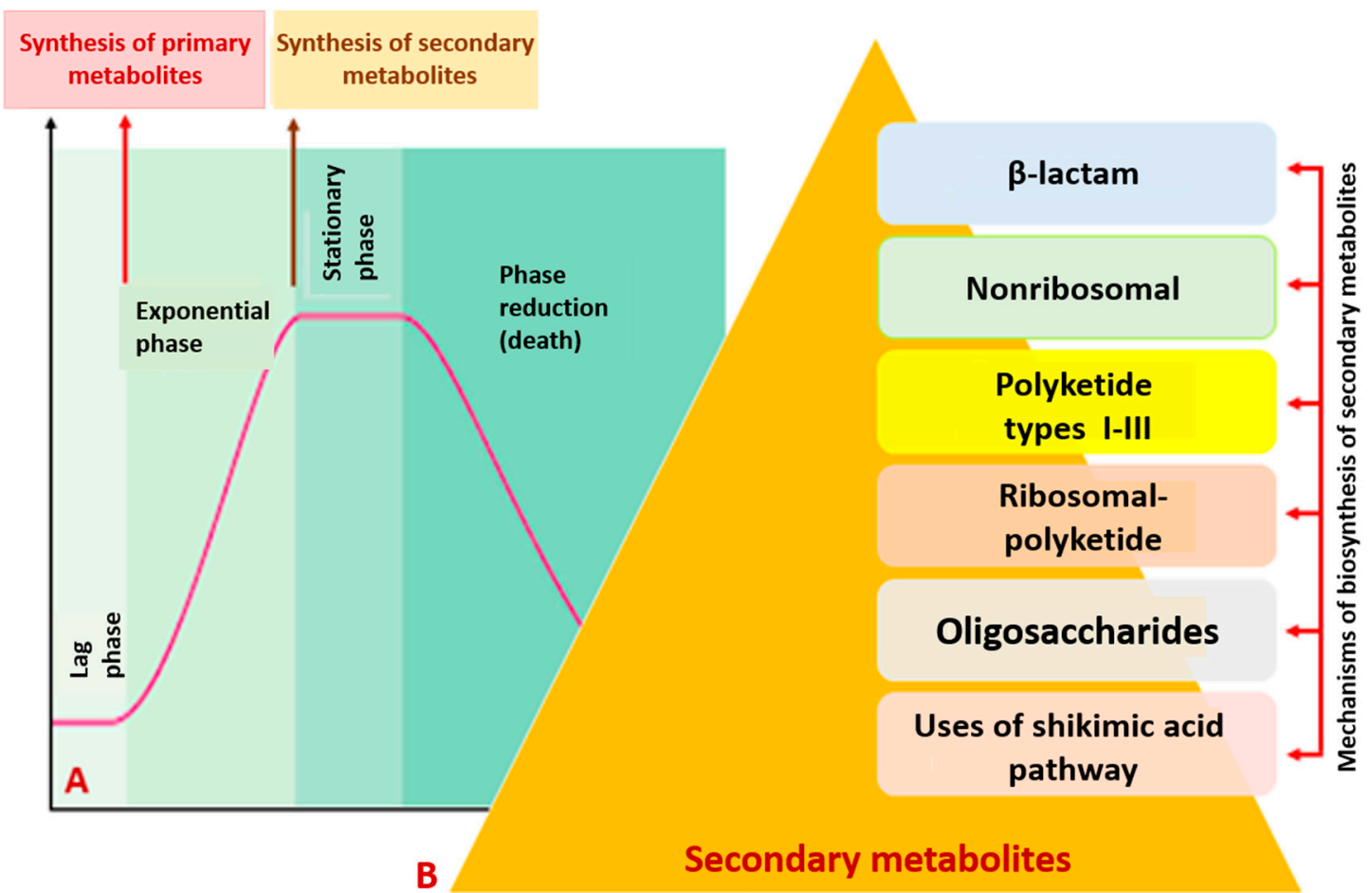

Figure 1. Production of secondary metabolites occurs at the end of the exponential and at the beginning of the stationary phases of bacterial growth. (A) Various mechanisms of biosynthesis of secondary metabolites in bacteria (B).

Unlike primary metabolites, the biosynthetic pathways utilized to produce these molecules are numerous and have not been fully understood $[8,10]$. For biosynthesis, bacteria use multi-stage biosynthesis pathways, which involve specific enzymes or multi-enzyme complexes, being intermediate or end products of intracellular metabolism. Biosynthesis includes cascade regulations, the mechanisms of which have been studied at the transcription level [12].

Among the key pathways of biosynthesis of secondary metabolites with antibacterial activities, the best characterized are non-ribosomal (with peptide synthetase as the key enzyme), $\beta$-lactam, polyketide (types I-III, with polyketide synthase as the key enzyme), ribosomal- polyketide, oligosaccharide and shikimate pathways (Figure 1B).

The significantly increased interest in obtaining new antibiotic agents derived from secondary metabolites of marine bacteria is associated with the advances in biotechnology that have been made in recent decades [12,13]. They are based on the revealed mechanism of synthesis of major microbial metabolite classes by means of polyketide synthase $[14,15]$ and non-ribosomal peptide synthetase [16,17], which are biosynthetic pathways extensively utilized by marine microorganisms for producing antimicrobial substances [18].

\section{Antimicrobial Substances of Marine Microorganisms}

Microorganisms from terrestrial ecosystems and their metabolites have always been a source of many biologically active compounds applied in medicine, the pharmaceutical industry and agriculture. 
After years of intensive studies of terrestrial microorganisms, attention was focused on aquatic ecosystems of the World Ocean $[1,5,19]$. Temperature conversions, hydrostatic pressure, variable salinity and oxygen concentration are the factors that cause the rich taxonomic diversity of marine biota, in which bacteria and fungi constitute a substantial part, provide a rich resource of chemical products and are considered a promising source of a large number of biologically active compounds $[3,7,20,21]$.

One of the first researchers to reveal the antagonistic interactions of some marine bacteria with causative agents of dangerous infections (Bacillus anthracis and Vibrio cholerae) was V. de Giaxa in 1889. In his work "Üeber das Verhalten einiger pathogener Mikroorganismen im Meerwasser", he showed that in the case of combined cultivation with marine bacteria, these terrestrial pathogens lost their ability to cause infection in the experiment (cited by [22,23]). However, in those years, this article did not receive the due attention of researchers.

The issue of competitive interaction of marine bacteria and some members of the family Enterobacteriaceae was raised again only in the 1940s by S. Kiribayashi, T. Aida (1941), B.D. Rosenfeld, C.E. ZoBell (1947) and others. The results of the studies conducted in that period showed for the first time that the mortality of pathogenic enterobacteria in sea water was a consequence of the toxic effect of "antibiotics produced by marine microorganisms" (ZoBell, 1947) and, to a lesser extent, due to the salinity and osmotic pressure of water (cited by [22]). At the same time, an attempt was made to isolate these substances. A total of 58 species of marine bacteria, members of the genera Actinomyces, Bacillus, Micrococcus and Serratia, were tested; of them, nine strains were identified as producers of antibacterial substances antagonistically interacting with Gram-positive microorganisms $[19,22,23]$.

The growing worldwide interest in the study of biologically active metabolites produced by marine bacteria resulted from the accumulation of knowledge about true marine microorganisms. The modern scientific paradigm is consistent with the concept proposed in the middle of the 20th century by the academicians B.L. Isachenko (1871-1948) and Claude E. ZoBell (1904-1989), the founders of marine microbiology who explained the autochthonous existence of marine bacteria and their taxonomic uniqueness (cited by [23]). Subsequent discoveries have shown that marine biota are comprised of a specific taxa of prokaryotes, fungi and other microorganisms distributed ubiquitously. They are active participants in the cycle of matter in water and bottom sediments of the ocean, as well as sources for the production and isolation of specific peptide-based metabolites [20,23-25].

The history of study of secondary metabolites from marine bacteria is an example of the joint efforts and achievements of microbiologists, chemists, biochemists, molecular biologists and geneticists. The discovery of the phenomenon of unusual peptides synthesized in microorganisms independently of ribosomes and RNA was followed by a long series of findings and evidence of extremely diverse natural bacterial metabolites exhibiting antibiotic and antitumor activities (Table 2).

Table 2. Promising secondary metabolites with antimicrobial activity isolated from marine bacteria.

\begin{tabular}{|c|c|c|c|c|}
\hline Metabolite & Producer & Inhibiting & $\begin{array}{c}\text { Active } \\
\text { Concentration }\end{array}$ & References \\
\hline Bogorol A & Bacillus sp. & $\begin{array}{c}\text { Methicillin-resistant } \\
\text { Staphylococcus aureus (MRSA) }\end{array}$ & $2 \mu \mathrm{g} / \mathrm{mL}(\mathrm{MIC})$ & {$[26,27]$} \\
\hline Loloatin B & Bacillus sp. & $\begin{array}{l}\text { Methicillin-resistant } S \text {. aureus } \\
\text { (MRSA), vancomycin-resistant } \\
\text { Enterococcus faecium (VRE) }\end{array}$ & $1-2 \mu \mathrm{g} / \mathrm{mL}$ (MIC) & {$[28,29]$} \\
\hline Tauramamide & $\begin{array}{l}\text { Brevibacillus } \\
\text { laterosporus }\end{array}$ & Enterococcus sp. & $0.1 \mu \mathrm{g} / \mathrm{mL}(\mathrm{MIC})$ & {$[30,31]$} \\
\hline Halobacillin & $\begin{array}{l}\text { Bacillus sp. } \\
\text { CND-914 }\end{array}$ & $\begin{array}{l}\text { S. aureus, } P \text {. vulgaris and } E \text {. } \\
\text { faecalis. Human HCT-116 } \\
\text { cancer cells }\end{array}$ & $0.98 \mu \mathrm{g} / \mathrm{mL}(\mathrm{IC} 50)$ & {$[4,32]$} \\
\hline Macrolactin S & $\begin{array}{c}\text { Bacillus } \\
\text { amyloliquefaciens }\end{array}$ & Escherichia coli, S. aureus & $\begin{array}{l}0.1-0.3 \mu \mathrm{g} / \mathrm{mL} \\
(\mathrm{MIC})\end{array}$ & {$[33,34]$} \\
\hline Macrolactin V & B. amyloliquefaciens & E. coli, Bacillus subtilis, S. aureus & $0.1 \mu \mathrm{g} / \mathrm{mL}(\mathrm{MIC})$ & {$[33,34]$} \\
\hline
\end{tabular}


Table 2. Cont.

\begin{tabular}{ccccc}
\hline Metabolite & Producer & Inhibiting & $\begin{array}{c}\text { Active } \\
\text { Concentration }\end{array}$ & References \\
\hline Bacillistatins & Bacillus silvestris & Streptococcus pneumonia & $0.5-2 \mu \mathrm{g} / \mathrm{mL}\left(\mathrm{GI}_{50}\right)$ & {$[35]$} \\
\hline Triopeptid TP-1161 & Nocardiopsis sp. & $\begin{array}{c}\text { Vancomycin-resistant } \\
\text { Enterococcus faecium }(\mathrm{VRE})\end{array}$ & $1.0 \mu \mathrm{g} / \mathrm{mL}(\mathrm{MIC})$ & {$[36-39]$} \\
\hline Halocintin & $\begin{array}{c}\text { Halocynthia } \\
\text { papillosa }\end{array}$ & $\begin{array}{c}\text { Micrococcus luteus, Bacillus } \\
\text { megaterium, Aerococcus viridans, } \\
\text { S. aureus, Enterococcus faecalis }\end{array}$ & $0.39-50 \mu \mathrm{M}(\mathrm{MBC})$ & {$[40,41]$} \\
\hline Indigoidin & Phaeobacter sp. & Vibrio fischeri & $\mathrm{n} / \mathrm{d}$ & {$[42,43]$} \\
\hline Unnarrmicins A, C & Photobacterium sp. & Pseudovibrio sp. & $7-18 \mu \mathrm{g} / \mathrm{disk}$ & {$[44,45]$} \\
\hline Ngercheumicins & Photobacterium sp. & Gram (-) bacteria & $\mathrm{n} / \mathrm{d}$ & {$[31,46]$} \\
\hline Solonamidin A & Photobacterium sp. & $\begin{array}{c}\text { S. aureus, methicillin-resistant } \\
\text { S. aureus } \text { (MRSA) }\end{array}$ & $\mathrm{n} / \mathrm{d}$ & {$[3,47]$} \\
\hline $\begin{array}{c}\text { Cyclo-peptides } \\
\text { Ariakemicins A, B }\end{array}$ & Pseudomonas sp. & $\begin{array}{c}\text { S. aureus, M. luteus, B. subtilis, } \\
\text { E. coli, Vibrio anguillarum }\end{array}$ & $\mathrm{n} / \mathrm{d}$ & {$[3,4,48,49]$} \\
\hline Turnagainolides A, \\
B
\end{tabular}

\section{Marine Bacteria-An Inexhaustible Source of Non-Ribosomal Synthesized Secondary Metabolites}

During their life cycle, marine microorganisms actively synthesize secondary metabolites which are low-molecular-weight peptides. They represent specific protein fragments that, in addition to being sources of nitrogen and amino acids, perform numerous biological functions $[5,7,11,53]$. These substances were derived from algae, marine bacteria and fungi. The anti-infection activity of marine peptides has been shown to depend on their structural properties, amino acid composition and sequence, as well as on the habitat conditions for producer bacteria $[7,53,54]$ (Table 2).

The major part of marine bacteria is exposed to extreme conditions of high pressure, salinity, low temperature and lack of sunlight. These factors caused them to develop the unique properties and the ability to biosynthesize substances with unusual characteristics, different from their terrestrial counterparts. To date, biological properties of only a small number of these peptides have been studied, but the proportion of described substances increases each year, attracting increasingly more attention from researchers [11,54-56].

Most marine bacteria and other microorganisms use numerous gene clusters for metabolite biosynthesis $[7,56]$. Studies of genome sequences have shown that a significant part of them is responsible for the biosynthesis of secondary metabolites. For example, among marine microorganisms, isolates of the genus Bacillus are referred to as phylogenetically heterogeneous groups of marine bacteria. They need much nutrients and space, and, in order to compete with other bacteria, they synthesize a significant amount of secondary metabolites with pronounced antimicrobial activity, encoded by genes constituting up to $8 \%$ of the genome [54,57].

To date, dozens of metabolites, which are peptides consisting of 20-40 amino acids and used for inter- and intraspecific competition, have been isolated from various marine microorganisms $[5,7,54]$. Most of them are capable of quick inhibition or kill of a wide range of microbes. Other antimicrobial metabolites (proteins consisting of 100 or more amino acids) disrupt the structure or function of microbial cell membranes by binding to specific targets [58,59]. In the framework of the global program 
of search for antimicrobial alternatives to traditional antibiotics, results of more than 40 studies on finding new antimicrobial compounds isolated from marine bacteria and fungi have been published over the past 15 years [53,55,57].

In recent years, much of the attention of researchers has been focused on secondary metabolites of marine bacteria, which are products of nonribosomal biosynthesis considered a new class of natural antimicrobial agents that can potentially become an alternative to traditional antibiotics $[54,56,59,60]$.

It is known that more than $50 \%$ of the antimicrobial drugs used in clinical practice currently belong to the non-ribosomal peptides (NRP) or to the mixed polyketide-neribosomal peptide family, which are unusual in structure and possess various biological properties. Non-ribosomal synthesis is an original biosynthesis pathway that leads to a wide variety of products with a wide range of important biological properties $[5,7,58,59]$.

The capability of non-ribosomal peptide synthesis is widely distributed among marine bacteria. As a rule, these secondary metabolites show a wide range of biological activities (antimicrobial, antitumor, antiviral and antifungal), a variety of pharmacological properties and an extremely high structural diversity [58-60]. About $70 \%$ of them are secondary metabolites of marine bacteria, which provide an inexhaustible source of diverse classes of non-ribosomally synthesized secondary metabolites, of which substances (lipopeptides, polypeptides, macrolactones, fatty acids, polyketides, lipoamides and isocoumarins) are cyclic branched peptide compounds with unusual structures and structural templates of novel natural antibiotics [59,61-63].

A special mechanism for the synthesis of NRPs mediates chemical modifications of the included residues, such as epimerization or methylation, as well as a wide variety of peptide designs, due to the arrangement of different monomers in certain positions.

The structural and compositional diversity of these peptides, as well as a wide range of important biological and pharmacological activities, is required in the creation of electronic databases, for example, the resources of PubChem, Peptaibol or Norin, which contain hundreds of NRPs, the list of which is constantly updated $[54,57,59]$.

It is known that more than $50 \%$ of the drugs used in clinical practice currently belong to the non-ribosomal peptides (NRP) or to the mixed polyketide-neribosomal peptide family, which are unusual in structure and possess various biological properties. Non-ribosomal synthesis is an original biosynthesis pathway that leads to a wide variety of products with a wide range of important biological properties. In particular, marine bacteria are an important bioresource for the production of NRP with numerous pharmaceutical applications. About $70 \%$ of them are secondary metabolites of marine bacteria and have antimicrobial, antiviral, cytostatic, immunomolyulosa or antimalarial activity.

In the second half of the 20th century, this biosynthesis mechanism was simulated in a laboratory to obtain antimicrobial peptides produced by marine isolates of Bacillus sp., in which the pharmacologically-induced inhibition of ribosomes or RNA removal did not prevent protein synthesis [64].

It has been established that the adenosine triphosphate (ATP)-dependent synthesis of non-ribosomal peptides (NRP) occurs by means of peptide synthetase, an enzyme complex independent of messenger RNA, transmitting the genetic information from DNA to ribosomes, where the amino acid sequence of protein products of gene expression is determined $[61,63,65]$.

Operation of this "assembly line" depends solely on the activity of peptide synthetase, which is a multi-domain modular enzyme complex. It catalyzes the ATP-dependent synthesis of important peptide products with antimicrobial activity from specific sequences of proteinogenic and non-encoded amino acid substrates. The process includes three key sequential stages: acetylation, thyolization, and condensation with the involvement of the same-name key domains and peptide carrier protein $[18,59,62]$ (Figure 2). 


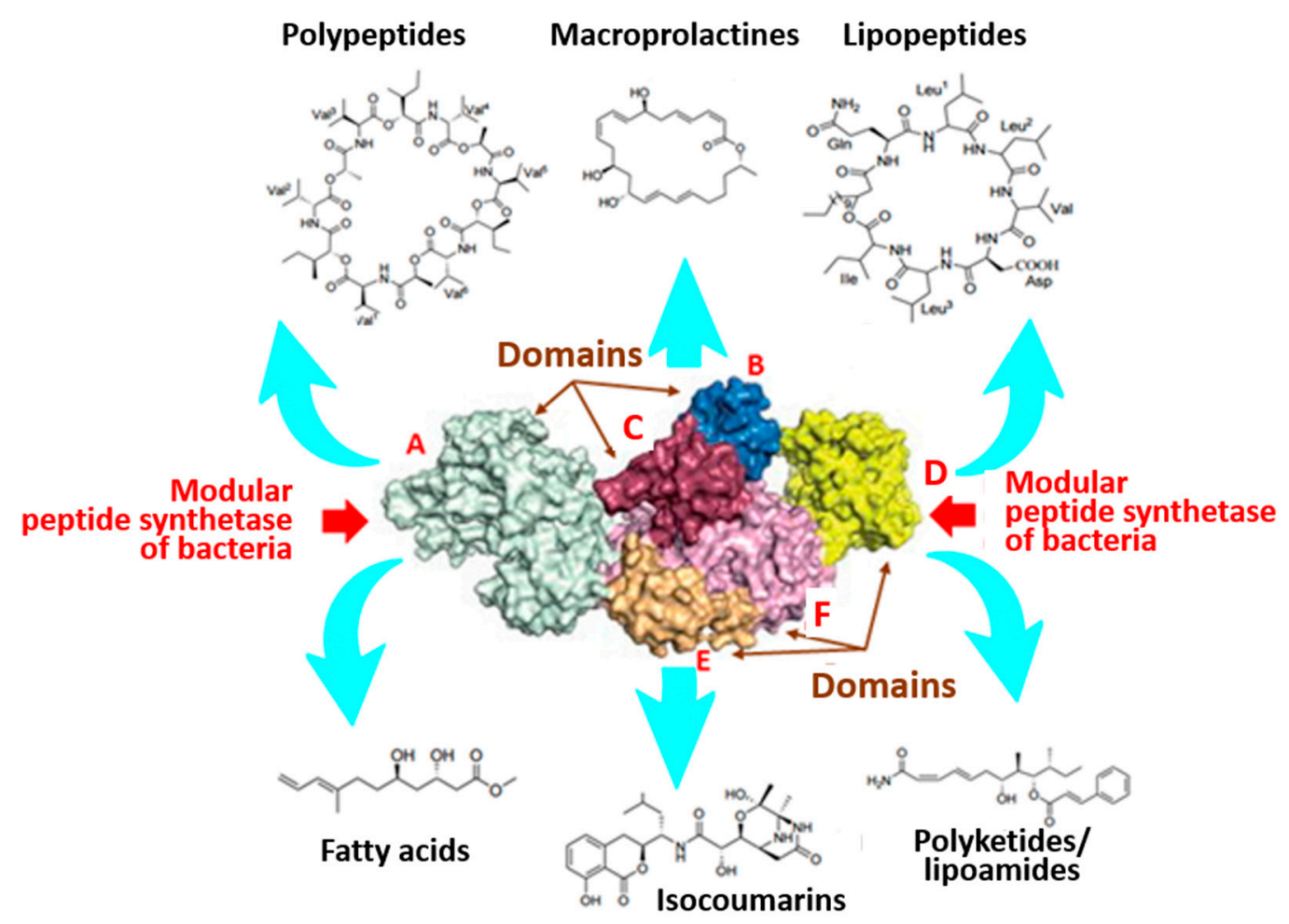

Figure 2. Structure of macrolactin of bacteria constituting the basis of non-ribosomal synthesis and structural diversity of synthesized metabolites. Domains are as follows: (A) carrier peptide; (B) acetylation; (C) condensation; (D) thyosterase domains; (E,F) formyltransferase domains.

Unlike ribosomal synthesis, where the sequence of 20-22 natural amino acids is determined by the primary structure of RNA, the ribosome-independent mechanism provides assembly of relatively short NRPs. They consist of a set of non-encoded (non-proteinogenic) amino acids, the sequence of which is strictly determined by the structure of the polyenzyme complex. To date, almost 150 such amino acids and dozens of thousands of their combinations are known, which explains the wide structural variety of NRPs, as well as their physical and chemical stability and conformational plasticity $[58,60,63]$.

Because of the high pharmacological activity of the non-ribosomal synthesis products, much effort has been applied in recent years to the study of the promising and unusual biosynthesis mechanisms and the diversity of pharmacological properties of NRPs. To date, several pathways of nonribosomal synthesis of peptides have been characterized from both terrestrial (human commensals and pathogens) and marine species of bacteria, which are comprehensively considered enough in recent reviews [59,60,64].

It should be noted that, from an evolutionary aspect, the understanding of non-ribosomal biosynthesis mechanisms has evolved from the erroneous view of peptide synthetase as a precursor of ribosomes, as well as from the discovery of the "thiotemplate" mechanism $[62,65]$ and its revision in connection with the advent of the modern modular-domain "multiple carrier model" $[58,63,64]$. In the present review, we consider only some of the antimicrobial peptide substances that are products of this biosynthesis pathway, being components of secondary metabolites of marine bacteria.

\subsection{Cyclic Lipopeptides (cLPs)}

Cyclic lipopeptides (cLPs) are common metabolites synthesized by various bacterial genera and are of interest as substances having various biological activities (Figure 2). Lipopeptides of marine bacteria consist of a short cyclic oligopeptide (backbone) bound to fatty acids (tail) and show strong antibacterial activity against common human, animal and plant pathogens, by which these metabolites have attracted attention as potential natural antibiotic agents (Table 2). 
Lipopeptides are divided into three families: iturins, fengycins and surfactins [66-68]. In its chemical structure, the peptide backbone is represented by seven (iturins and surfactins) or 10 (iturins) amino acids bound to $\beta$-hydroxy- (fengycins and surfactins) or $\beta$-amino- (iturins) fatty acids with the number of carbon atoms being from C-10 to C-16 (surfactins), from C-14 to C-17 (iturins) and from C-14 to C-18 (fengycins). Each family is subdivided into homologous subfamilies depending on the position of a certain amino acid in the peptide ring $[66,68]$. The examples of well-characterized lipopeptide antibiotics, which are metabolites of marine bacteria, are tauromamid, halobacillin and methylhalobacillin [4,30-32].

Tauromamid is a relatively new non-ribosomally biosynthesized antibiotic [30,31] (Table 2), belonging to the group of cyclic lipopeptides (like daptomycin, the first permitted antibiotic of this class). It is produced by the marine bacterial isolate of Brevibacillus lateosporus PNG276, inhabiting the Gulf of Papua [31]. Tauromamid has a strong and selective inhibitory action on the Gram-positive pathogen Enterococcus sp., as well as exhibiting unexpressed activity against the methicillin-resistant Staphylococcus aureus (MRSA; MIC $=200 \mu \mathrm{g} / \mathrm{mL}$ ) and Candida albicans (MIC $=50 \mu \mathrm{g} / \mathrm{mL}$ ) [30,31].

Halobacillin and methylhalobacillin are two cyclic lipopeptides isolated from bacteria inhabiting deep-sea sediment in the Gulf of California, Mexico [32]. Halobacillin is also one of the most effective known biosurfactants [4]. This antibiotic inhibits the growth of human colon tumor cells (HCT-116) at $\mathrm{IC}_{50} 0.98 \mu \mathrm{g} / \mathrm{mL}$ and exhibits analogous, but lower than surfactin (a known surfactant antibiotic isolated from terrestrial strains of Bacillus subtilis) antimicrobial activity against S. aureus, Proteus vulgaris and Enterococcus faecalis [4,32] (Table 2).

The wide distribution of cLPs among secondary metabolites of marine bacteria is evidenced by the fact that they make up the major part of products of marine isolates from Bacillus sp., one of the most common inhabitants of the World Ocean [3].

\subsection{Polyketides/Lipoamides}

Polyketides are extremely large classes of secondary metabolites that contain acyl-coenzyme A and constitute the basis of many pharmaceutical, agrochemical and veterinary drugs. The biosynthesis of these metabolites occurs with the involvement of multimodular megasynthases known as polyketide synthases $[14,15]$. Thanks to this biosynthesis mechanism, polyketides show an amazing structural and antimicrobial diversity. Several metabolites with antibiotic action from marine isolates of B. lateosporus, belonging to the family of polyketides, such as basiliskamide A and B, as well as tupusleiamide $\mathrm{A}$ and $\mathrm{B}$, have been characterized recently. These antibiotics exhibited antifungal activity against Candida albicans (MIC $=1.0$ and $3.1 \mu \mathrm{g} / \mathrm{mL}$ ) and Aspergillus fumigatus (MIC $=2.5$ and $5.0 \mu \mathrm{g} / \mathrm{mL}$ ) [14,15,45].

Two polyketides with unique antimicrobial and antitumor properties were isolated in 2012 from the marine bacterium Bacillus licheniformis from a sediment core sample collected on the southern Iodo reef, Republic of Korea. The antibiotics ieodoglucomides A and B in vitro showed antimicrobial activity against Gram-positive and Gram-negative pathogenic bacteria (MIC $=8-32 \mu \mathrm{g} / \mathrm{mL}$ ). In addition, ieodoglucomide B exhibited cytotoxic activity against lung cancer cell line $\left(\mathrm{GI}_{50}=25.18 \mu \mathrm{g} / \mathrm{mL}\right)$ and gastric cancer cell line $\left(\mathrm{GI}_{50}=17.78 \mu \mathrm{g} / \mathrm{mL}\right)$ [14].

The thiopeptide antibiotic TP-1161, isolated from the marine Gram-positive bacterium Nocardiopsis sp., belongs to the same structural group [36-38]. This antibiotic showed high antibacterial activity in vitro against clinical isolates of Gram-positive bacteria (with MIC varying from 0.25 to $4 \mu \mathrm{g} / \mathrm{mL}$ ), i.e., at concentrations comparable or lower than that of the reference antibiotic vancomycin. TP-1161 also inhibited the growth of vancomycin-resistant bacterial strains, including Enterococcus faecalis and Enterococcus faecium, at MIC $=1 \mu \mathrm{g} / \mathrm{mL}[38]$.

\section{Mechanisms of Antimicrobial Action of Antibacterial Peptides}

In recent years, a large group of secondary metabolites of different types, structures and mechanisms of antibacterial action has been isolated from a number of other marine bacteria $[3-5,7,8]$. Unlike those from terrestrial ecosystems, producers of antimicrobial peptides were mainly strains of 
Gram-positive marine bacteria $[7,9,10]$, despite Gram-negative prokaryotes dominating the marine environment $[21,22,68,69]$.

Most of the isolated antimicrobial metabolites are capable of rapidly killing a wide range of microbes. Large-sized antimicrobial proteins (>100 amino acids) are often lytic proteins that bind nutrients $[68,70]$ or destroy specific cell patterns [71-73], causing DNA degradation [73,74] and inhibiting intracellular synthesis of peptidoglycan [75-77] and specific proteins by disrupting the structure or function of microbial cell membranes [7,54,78,79] (Figure 3).

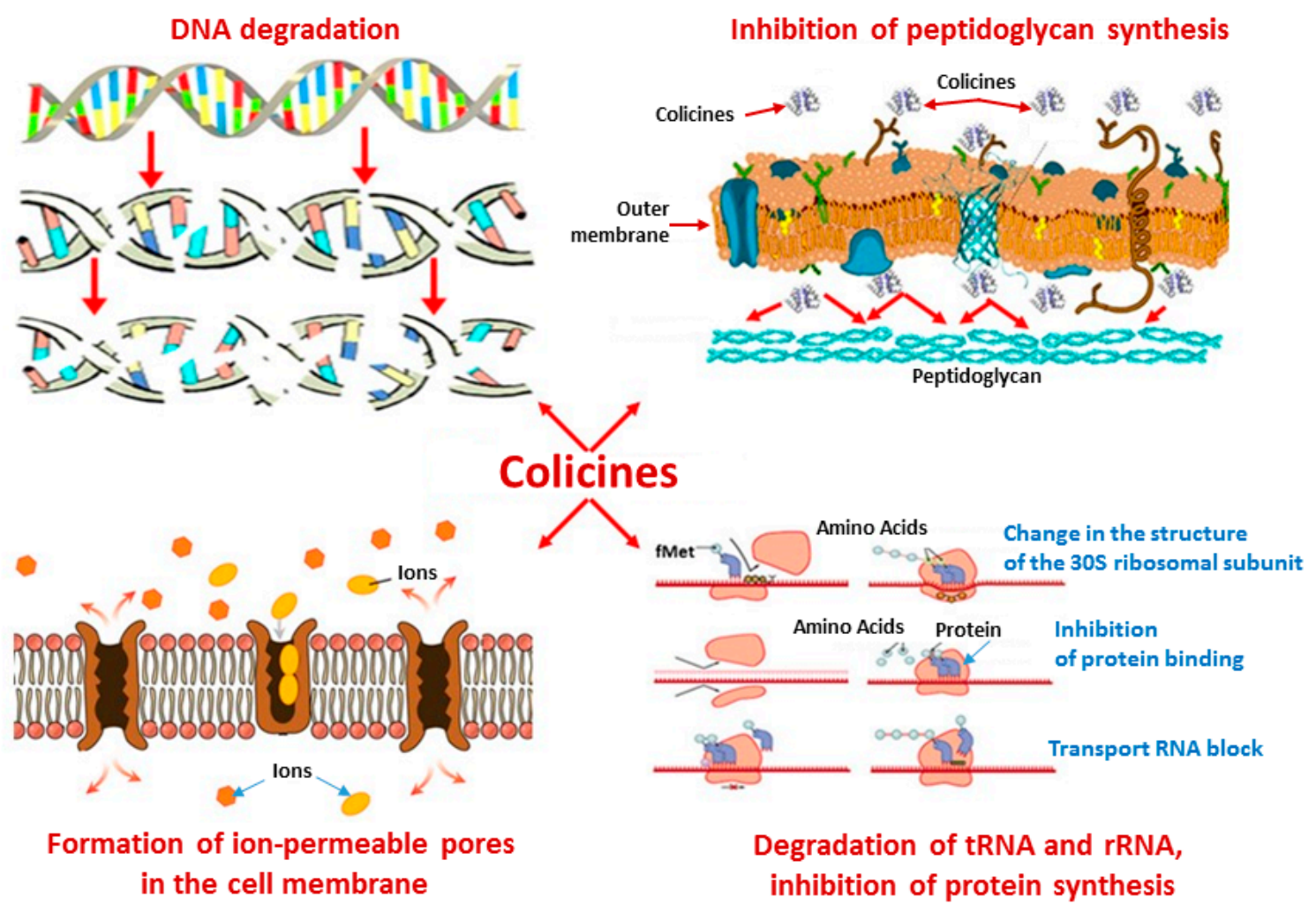

Figure 3. Key mechanisms of antimicrobial action of antibacterial peptides, which are secondary metabolites of marine bacteria (diagram by authors). Notes: tRNA-transfer ribonucleic acid; rRNA-ribosomal ribonucleic acid.

In recent years, two accessible databases have been created for storing and querying information on almost two hundred antibacterial peptides-BACTIBASE [80] and BAGEL [81,82]. Moreover, members of this metabolite class are mentioned in other relevant databases, such as APD3 [83], ANTIMIC [84], CyBase [85] or StraPep [86], the use of which in the mode suggests the antibacterial activity of the substances obtained.

Despite the fact that the isolation and study of secondary metabolites from marine bacteria is currently at the initial stage, the obtained results show them as the most promising agents to control infectious diseases of fish. This is especially important in light of the current trend of the increasing proportion of marine aquaculture in global seafood production and its increasing role in the world's fisheries [87-89].

In addition, marine-derived metabolites have demonstrated their immense potential to be used as natural preservatives of foods, medical and veterinary therapeutic drugs or phytosanitary agents for plant protection $[4,88,90,91]$. Their antitumor resource $[4,32,66,92]$ and anti-virus $[5,64]$ and antifungal activities [3-5] are very noteworthy and promising. 


\section{Conclusions}

Marine bacteria are an extremely rich source of structurally diverse classes of protein-based secondary metabolites. In recent years, significant progress has been made in our understanding of the complex mechanisms of their non-ribosomal biosynthesis. These natural metabolic byproducts of marine bacteria have a wide range of antimicrobial activities, low rate of elimination from the organism, high specificity to cell targets and reduced risk of undesirable side effects. Because of these properties, they are already considered as a source of effective biologically active therapeutic agents that can become an alternative to traditional antimicrobial drugs.

Modern biotechnologies of invention and development of novel antibiotics having a medical value are based on application of natural strategies of non-ribosomal peptide synthesis $[4,9,10]$. Revealing the mechanisms and potential of this type of metabolite production in terrestrial and marine bacteria is not only of fundamental, but also of great practical importance. In human pathogens, this biosynthetic pathway probably causes the emergence of microbial isolates with multidrug resistance. Under these conditions, the activity of peptide synthetase and clusters of the genes responsible for non-ribosomal synthesis become a new target for the strategy of treatment of infections caused by drug-resistant forms of bacteria $[3,5,91,92]$.

With regard to marine bacteria and their secondary metabolites, the targeted control of biosynthesis mechanisms by using the metabolic engineering methods to create hybrid peptides or obtain hybrid peptide synthetases by disrupting the target gene of non-ribosomal synthesis is now one of the noteworthy trends in modern biotechnology. This pathway becomes not only one of the most promising approaches to the development of novel antibiotics, but also a potential target for controlling the exocrine activity of pathogenic bacteria and, consequently, their viability [5,93-95].

The range of active antimicrobial agents derived from marine bacteria, discovered and tested in recent years, indicate a high pharmacological potential of their secondary metabolites, and the study of these peptides is expected to be an interesting and fruitful activity in the coming years.

Author Contributions: Conceptualization, A.B. and M.V.; methodology, A.B. and M.V.; validation, A.B., M.V. and N.N.; resources, M.V.; writing-review and editing, A.B.; visualization, N.N.; supervision, M.V.; project administration, A.B.

Funding: The study was supported by the Far Eastern Branch, Russian Academy of Sciences, within the framework of the "Far East" Integrated Program for Basic Research, project No. 18-5-099.

Conflicts of Interest: The authors declare that they have no conflict of interest.

\section{References}

1. World Health Organization (WHO). Antimicrobial Resistance. 2015. Available online: http://www.who.int (accessed on 23 February 2019).

2. Chokshi, A.; Sifri, Z.; Cennimo, D.; Horng, H. Global Contributors to Antibiotic Resistance. J. Glob. Infect. Dis. 2019, 11, 36-42. [CrossRef] [PubMed]

3. Kang, H.K.; Seo, C.H.; Park, Y. Marine Peptides and Their Anti-Infective Activities. Mar. Drugs 2015, 13, 618-654. [CrossRef] [PubMed]

4. Mondol, M.; Shin, H.; Islam, M. Diversity of Secondary Metabolites from Marine Bacillus Species: Chemistry and Biological Activity. Mar. Drugs 2013, 11, 2846-2872. [CrossRef] [PubMed]

5. Böhringer, N.; Fisch, K.M.; Schillo, D.; Bara, R.; Hertzer, C.; Grein, F.; Eisenbarth, J.H.; Kaligis, F.; Schneider, T.; Wägele, H.; et al. Antimicrobial Potential of Bacteria Associated with Marine Sea Slugs from North Sulawesi, Indonesia. Front. Microbiol. 2017, 8, 1092. [CrossRef] [PubMed]

6. Andryukov, B.G.; Zaporozhets, T.S.; Besednova, N.N. Promising Strategies for Finding New Means of Combating Infectious Diseases. Antibiot. Chemother. 2018, 63, 44-55. [CrossRef]

7. Andryukov, B.G.; Mikhaylov, V.V.; Besednova, N.N.; Zaporozhets, T.S.; Bynina, M.P.; Matosova, E.V. The Bacteriocinogenic Potential of Marine Microorganisms. Russ. J. Mar. Biol. 2018, 44, 433-441. [CrossRef]

8. Gokulan, K.; Khare, S.; Cerniglia, C. Metabolic pathways. Production of Secondary Metabolites of Bacteria. Encycl. Food Microbiol. 2014, 561-569. [CrossRef] 
9. Wang, Y.-P.; Lei, Q.-Y. Metabolite sensing and signaling in cell metabolism. Signal Transduct. Target. Ther. 2018, 3, 30. [CrossRef]

10. Pinu, F.R.; Villas-Boas, S.G.; Aggio, R. Analysis of Intracellular Metabolites from Microorganisms: Quenching and Extraction Protocols. Metabolites 2017, 7, 53. [CrossRef]

11. Niu, G.Q.; Tan, H.R. Biosynthesis and regulation of secondary metabolites in microorganisms. Life Sci. 2013, 56, 581-583. [CrossRef]

12. Baral, B.; Akhgari, A.; Metsä-Ketelä, M. Activation of microbial secondary metabolic pathways: Avenues and challenges. Synth. Syst. Biotechnol. 2018, 3, 163-178. [CrossRef]

13. Wright, G.D. Something old, something new: revisiting natural products in antibiotic drug discovery. Can. J. Microbiol. 2014, 60, 147-154. [CrossRef] [PubMed]

14. Tareq, F.S.; Kim, J.H.; Lee, M.A.; Lee, H.S.; Lee, Y.J.; Lee, J.S.; Shin, H.J. Ieodoglucomides A and B from a marine-derived bacterium Bacillus licheniformis. Org. Lett. 2012, 14, 1464-1467. [CrossRef] [PubMed]

15. Robbins, T.; Liu, Y.C.; Cane, D.E.; Khosla, C. Structure and mechanism of assembly line polyketide synthases. Curr. Opin. Struct. Biol. 2016, 41, 10-18. [CrossRef] [PubMed]

16. Strieker, M.; Tanović, A.; Marahiel, M.A. Nonribosomal peptide synthetases: structures and dynamics. Curr. Opin. Struct. Biol. 2010, 20, 234-240. [CrossRef] [PubMed]

17. Gulick, A.M. Nonribosomal peptide synthetase biosynthetic clusters of ESKAPE pathogens. Nat. Prod. Rep. 2017, 34, 981-1009. [CrossRef] [PubMed]

18. Alfermann, J.; Sun, X.; Mayerthaler, F.; Morrell, T.E.; Dehling, E.; Volkmann, G.; Komatsuzaki, T.; Yang, H.; Mootz, H.D. FRET monitoring of a nonribosomal peptide synthetase. Nat. Chem. Biol. 2017, 13, 1009-1015. [CrossRef] [PubMed]

19. Choudhary, A.; Naughton, L.M.; Montánchez, I.; Dobson, A.D.W.; Rai, D.K. Current Status and Future Prospects of Marine Natural Products (MNPs) as Antimicrobials. Mar. Drugs 2017, 15, 272. [CrossRef]

20. Chen, D.; Qian, X. A Brief History of Bacteria: The Everlasting Game Between Humans and Bacteria; World Scientific Publishing Company: Singapore, 2017; p. 296.

21. Mikhailov, V.V.; Pivkin, M.V. The Study of Marine Bacteria and Fungi; Some results and prospects of research; Bulletin of the Far Eastern Branch of the Russian Academy of Sciences: Vladivostok, Russia, 2014; Volume 173, pp. 149-156.

22. Stonik, V.A.; Mikhailov, V.V. Prospects for the use of microorganisms of the marginal seas of the Far East and the Arctic for the search and practical application of natural bioactive substances. In Scientific and Technical Problems of the Development of the Arctic; Publishing Academic Book: Moscow, Russia, 2015; pp. 412-425.

23. Timmermans, M.L.; Paudel, Y.P.; Ross, A.C. Investigating the Biosynthesis of Natural Products from Marine Proteobacteria: A Survey of Molecules and Strategies. Mar. Drugs 2017, 15, 235. [CrossRef]

24. Manivasagan, P.; Venkatesan, J.; Sivakumar, K.; Kim, S.K. Pharmaceutically active secondary metabolites of marine actinobacteria. Microbiol. Res. 2014, 169, 262-278. [CrossRef]

25. Versluis, D.; Nijsse, B.; Naim, M.A.; Koehorst, J.J.; Wiese, J.; Imhoff, J.F.; Schaap, P.J.; van Passel, M.W.J.; Smidt, H.; Sipkema, D. Comparative Genomics Highlights Symbiotic Capacities and High Metabolic Flexibility of the Marine Genus Pseudovibrio. Genome Biol. Evol. 2018, 10, 125-142. [CrossRef]

26. Yamashita, T.; Kuranaga, T.; Inoue, M. Solid-Phase Total Synthesis of Bogorol A: Stereocontrolled Construction of Thermodynamically Unfavored (E)-2-Amino-2-butenamide. Org. Lett. 2015, 17, 2170-2173. [CrossRef] [PubMed]

27. Jang, C.H.; Park, H.; Cho, Y.B.; Choi, C.H. Effect of vancomycin-coated tympanostomy tubes on methicillin-resistant Staphylococcus aureus biofilm formation: In Vitro study. J. Laryngol. Otol. 2010, 124, 594-598. [CrossRef] [PubMed]

28. Tuin, A.W.; Grotenbreg, G.M.; Spalburg, E.; de Neeling, A.J.; Mars-Groenendijk, R.H.; van der Marel, G.A.; Noort, D.; Overkleeft, H.S.; Overhand, M. Structural and biological evaluation of some loloatin C analogues. Bioorg. Med. Chem. 2009, 17, 6233-6240. [CrossRef] [PubMed]

29. Rahman, H.; Austin, B.; Mitchell, W.J.; Morris, P.C.; Jamieson, D.J.; Adams, D.R.; Spragg, A.M.; Schweizer, M. Novel anti-infective compounds from marine bacteria. Mar. Drugs 2010, 8, 498-518. [CrossRef] [PubMed]

30. Desjardine, K.; Pereira, A.; Wright, H.; Matainaho, T.; Kelly, M.; Andersen, R.J. Tauramamide, a lipopeptide antibiotic produced in culture by Brevibacillus laterosporus isolated from a marine habitat: Structure elucidation and synthesis. J. Nat. Prod. 2007, 70, 1850-1853. [CrossRef] [PubMed] 
31. Agrawal, S.; Acharya, D.; Adholeya, A.; Barrow, C.J.; Deshmukh, S.K. Nonribosomal Peptides from Marine Microbes and Their Antimicrobial and Anticancer Potential. Front. Pharmacol. 2017, 8, 828. [CrossRef] [PubMed]

32. Zhou, Z.F.; Guo, Y.W. Bioactive natural products from Chinese marine flora and fauna. Acta Pharmacol. Sin. 2012, 33, 1159-1169. [CrossRef] [PubMed]

33. Yuan, J.; Zhao, M.; Li, R.; Huang, Q.; Rensing, C.; Raza, W.; Shen, Q. Antibacterial Compounds-Macrolactin Alters the Soil Bacterial Community and Abundance of the Gene Encoding PKS. Front. Microbiol. 2016, 7, 1904. [CrossRef] [PubMed]

34. Jung, J.W.; Kim, J.M.; Kwon, M.H.; Kim, D.H.; Kang, H.E. Pharmacokinetics of macrolactin A and 7-O-succinyl macrolactin A in mice. Xenobiotica 2014, 44, 547-554. [CrossRef] [PubMed]

35. Pettit, G.R.; Knight, J.C.; Herald, D.L.; Pettit, R.K.; Hogan, F.; Mukku, V.J.; Hamblin, J.S.; Dodson, M.J.; Chapuis, J.C. Antineoplastic agents. 570. Isolation and structure elucidation of bacillistatins 1 and 2 from a marine Bacillus silvestris. J. Nat. Prod. 2009, 72, 366-371. [CrossRef]

36. Raimundo, I.; Silva, S.G.; Costa, R.; Keller-Costa, T. Bioactive Secondary Metabolites from Octocoral-Associated Microbes-New Chances for Blue Growth. Mar. Drugs 2018, 16, 485. [CrossRef] [PubMed]

37. Engelhardt, K.; Degnes, K.F.; Zotchev, S.B. Isolation and characterization of the gene cluster for biosynthesis of the thiopeptide antibiotic TP-1161. Appl. Environ. Microbiol. 2010, 76, 7093-7101. [CrossRef] [PubMed]

38. Engelhardt, K.; Degnes, K.F.; Kemmler, M.; Bredholt, H.; Fjaervik, E.; Klinkenberg, G.; Sletta, H.; Ellingsen, T.E.; Zotchev, S.B. Production of a new thiopeptide antibiotic, TP-1161, by a marine Nocardiopsis species. Appl. Environ. Microbiol. 2010, 76, 4969-4976. [CrossRef] [PubMed]

39. Romero, J.; Feijoo, C.G.; Navarrete, P. Antibiotics in Aquaculture-Use, Abuse and Alternatives. Health and Environment in Aquaculture; Carvalho, E., Ed.; InTech Europe: Rijeka, Croatia, 2012; 200p.

40. Galinier, R.; Roger, E.; Sautiere, P.E.; Aumelas, A.; Banaigs, B.; Mitta, G. Halocyntin and papillosin, two new antimicrobial peptides isolated from hemocytes of the solitary tunicate, Halocynthia papillosa. J. Pept. Sci. 2009, 15, 48-55. [CrossRef] [PubMed]

41. Kojima, H.; Shinohara, R.; Itonori, S.; Ito, M. Characterization of a Novel Rhamnose-containing Acidic Glycosphingolipid from the Ascidian Halocynthia aurantium. J. Oleo Sci. 2017, 66, 285-295. [CrossRef] [PubMed]

42. Slightom, R.N.; Buchan, A. Surface colonization by marine roseobacters: Integrating genotype and phenotype. Appl. Environ. Microbiol. 2009, 75, 6027-6037. [CrossRef] [PubMed]

43. Cude, W.N.; Mooney, J.; Tavanaei, A.A.; Hadden, M.K.; Frank, A.M.; Gulvik, C.A.; May, A.L.; Buchan, A. Production of the antimicrobial secondary metabolite indigoidine contributes to competitive surface colonization by the marine roseobacter Phaeobacter sp. strain Y4I. Appl. Environ. Microbiol. 2012, 78, 4771-4780. [CrossRef] [PubMed]

44. Oku, N.; Kawabata, K.; Adachi, K.; Katsuta, A.; Shizuri, Y. Unnarmicins A and C, new antibacterial depsipeptides produced by marine bacterium Photobacterium sp. MBIC06485. J. Antibiot. 2008, 61, 11-17. [CrossRef] [PubMed]

45. Oku, N.; Adachi, K.; Matsuda, S.; Kasai, H.; Takatsaki, A.; Shizuri, Y. Ariakemicins A and B, novel polyketide-peptide antibiotics from a marine gliding bacterium of the genus Rapidithrix. Org. Lett. 2008, 10, 2481-2484. [CrossRef] [PubMed]

46. Fotie, J.; Morgan, R.E. Depsipeptides from microorganisms: A new class of antimalarials. Mini Rev. Med. Chem. 2008, 8, 1088-1094. [CrossRef] [PubMed]

47. Machado, H.; Månsson, M.; Gram, L. Draft Genome Sequence of Photobacterium halotolerans S2753, Producer of Bioactive Secondary Metabolites. Genome Announc. 2014, 2, e00535-14. [CrossRef] [PubMed]

48. Srivastava, A.; Mishra, V. Marine peptides act as novel chemotherapeutic agent. J. Microbiol. Exp. 2018, 6, 267-270.

49. Rungprom, W.; Siwu, E.R.O.; Lambert, L.K.; Dechsakulwatana, C.; Barden, M.C.; Kokpol, U.; Blanchfield, J.T.; Kita, M.; Garson, M.J. Cyclic tetrapeptides from marine bacteria associated with the seaweed Diginea sp. and the sponge Halisarca ectofibrosa. Tetrahedron 2008, 64, 3147-3152. [CrossRef]

50. Li, D.; Carr, G.; Zhang, Y.; Williams, D.E.; Amlani, A.; Bottriell, H.; Mui, A.L.; Andersen, R.J. Turnagainolides A and B, cyclic depsipeptides produced in culture by a Bacillus sp.: isolation, structure elucidation, and synthesis. J. Nat. Prod. 2011, 74, 1093-1099. [CrossRef] [PubMed] 
51. Hu, Y.; Phelan, V.; Ntai, I.; Farnet, C.M.; Zazopoulos, E.; Bachmann, B.O. Benzodiazepine biosynthesis in Streptomyces refuineus. Chem. Biol. 2007, 14, 691-701. [CrossRef] [PubMed]

52. Jang, H.M.; Kim, Y.B.; Choi, S.; Lee, Y.; Shin, S.G.; Unno, T.; Kim, Y.M. Prevalence of antibiotic resistance genes from effluent of coastal aquaculture, South Korea. Environ. Pollut. 2018, 233, 1049-1057. [CrossRef] [PubMed]

53. Yukiya, A. (Ed.) IAEA Bulletin: Protecting Our Marine Environment; IAEA Bulletin: Vienna, Austria, 2013.

54. Chen, E.; Chen, Q.; Chen, S.; Xu, B.; Ju, J.; Wang, H. Mathermycin, Lantibiotic marine Actinomycete Marinactinospora thermotolerans SCSIO 00652. Appl. Environ. Microbiol. 2017, 83, e00926-17. [CrossRef]

55. Karvonen, A.; Rintamäki, P.; Jokela, J.; Valtonen, E.T. Increasing water temperature and disease risks in aquatic systems: Climate change increases the risk of some, but not all, diseases. Int. J. Parasitol. 2010, 40, 1483-1488. [CrossRef]

56. Das, S.; Ward, L.R.; Burke, C. Prospects of using marine actinobacteria as probiotics in aquaculture. Appl. Microbiol. Biotechnol. 2008, 81, 419-429. [CrossRef]

57. Kim, S.K.; Bhatnagar, I.; Kang, K.H. Development of marine probiotics: Prospects and approach. Adv. Food Nutr. Res. 2012, 65, 353-362.

58. Felnagle, E.A.; Jackson, E.E.; Chan, Y.A.; Podevels, A.M.; Berti, A.D.; McMahon, M.D.; Thomas, M.G. Nonribosomal Peptide Synthetases Involved in the Production of Medically Relevant Natural Products. Mol. Pharm. 2008, 5, 191-211. [CrossRef] [PubMed]

59. Miller, B.R.; Gulick, A.M. Structural Biology of Nonribosomal Peptide Synthetases. Methods Mol. Biol. 2016, 1401, 3-29. [CrossRef] [PubMed]

60. Singh, M.; Chaudhary, S.; Sareen, D. Nonribosomal peptide synthetases: Identifying the cryptic gene clusters and decoding the natural product. J. Biosci. 2017, 42, 175-187. [CrossRef] [PubMed]

61. Reimer, J.M.; Harb, I.; Ovchinnikova, O.G.; Jiang, J.; Whitfield, C.; Schmeing, T.M. Structural Insight into a Novel Formyltransferase and Evolution to a Nonribosomal Peptide Synthetase Tailoring Domain. ACS Chem Biol. 2018, 13, 3161-3172. [CrossRef] [PubMed]

62. Klapper, M.; Braga, D.; Lackner, G.; Herbst, R.; Stallforth, P. Bacterial Alkaloid Biosynthesis: Structural Diversity via a Minimalistic Nonribosomal Peptide Synthetase. Cell Chem Biol. 2018, 25, 659-665.e9. [CrossRef]

63. Bloudoff, K.; Schmeing, T.M. Structural and functional aspects of the nonribosomal peptide synthetase condensation domain superfamily: Discovery, dissection and diversity. Biochim. Biophys. Acta Proteins Proteom. 2017, 1865, 1587-1604. [CrossRef] [PubMed]

64. Gratia, J.P. Andre Gratia: A forerunner in microbial and viral genetics. Genetics 2000, 156, 471-476. [PubMed]

65. Reimer, J.M.; Haque, A.S.; Tarry, M.J.; Schmeing, T.M. Piecing together nonribosomal peptide synthesis. Curr. Opin. Struct. Biol. 2018, 49, 104-113. [CrossRef]

66. Kitagaki, J.; Shi, G.; Miyauchi, S.; Murakami, S.; Yang, Y. Cyclic depsipeptides as potential cancer therapeutics. Anti Cancer Drugs 2015, 26, 259-271. [CrossRef]

67. Offret, C.; Desriac, F.; Le Chevalier, P.; Mounier, J.; Jégou, C.; Fleury, Y. Spotlight on Antimicrobial Metabolites from the Marine Bacteria Pseudoalteromonas: Chemodiversity and Ecological Significance. Mar. Drugs 2016, 14, 129. [CrossRef]

68. Giang, C.N.D.; Sebesvari, Z.; Renaud, F.; Rosendahl, I.; Minh, Q.H.; Amelung, W. Occurrence and Dissipation of the Antibiotics Sulfamethoxazole, Sulfadiazine, Trimethoprim, and Enrofloxacin in the Mekong Delta, Vietnam. PLoS ONE 2015, 10, e0131855.

69. Das, S.; Ward, L.R.; Burke, C. Screening of marine Streptomyces spp. for potential use as probiotics in aquaculture. Aquaculture 2010, 305, 32-41. [CrossRef]

70. Gao, X.Y.; Liu, Y.; Miao, L.L.; Li, E.W.; Hou, T.T.; Liu, Z.P. Mechanism of anti-Vibrio activity of marine probiotic strain Bacillus pumilus $\mathrm{H} 2$, and characterization of the active substance. AMB Express 2017, 7, 23. [CrossRef] [PubMed]

71. Kers, J.A.; Sharp, R.E.; Defusco, A.W.; Park, J.H.; Xu, J.; Pulse, M.E.; Weiss, W.J.; Handfield, M. Mutacin 1140 Lantibiotic Variants Are Efficacious Against Clostridium Difficile Infection. Front. Microbiol. 2018, 9, 415. [CrossRef] [PubMed]

72. Mohanty, B.R.; Sahoo, P.K. Edwardsiellosis in fish: A brief review. J. Biosci. 2007, 32, 1331-1344. [CrossRef] [PubMed] 
73. Phelan, R.W.; Barret, M.; Cotter, P.D.; O'Connor, P.; Chen, R.; Morrissey, J.; Dobson, A.; O'Gara, F.; Barbosa, T. Subtilomycin: A new lantibiotic from Bacillus subtilis strain MMA7 isolated from the marine sponge Haliclona simulans. Mar. Drugs 2013, 11, 1878-1898. [CrossRef] [PubMed]

74. Selvin, J.; Joseph, S.; Asha, K.R.; Manjusha, W.A.; Sangeetha, V.S.; Jayaseema, D.M.; Antony, M.C.; Denslin Vinitha, A.J. Antibacterial potential of antagonistic Streptomyces sp. isolated from marine sponge Dendrilla nigra. FEMS Microbiol. Ecol. 2004, 50, 117-122. [CrossRef]

75. Rivetti, I.; Fraschetti, S.; Lionello, P.; Zambianchi, E.; Boero, F. Global Warming and Mass Mortalities of Benthic Invertebrates in the Mediterranean Sea. PLoS ONE 2014, 9, e115655. [CrossRef] [PubMed]

76. Romanenko, L.A.; Uchino, M.; Kalinovskaya, N.I.; Mikhailov, V.V. Isolation, phylogenetic analysis and screening of marine mollusc-associated bacteria for antimicrobial, hemolytic and surface activities. Microbiol. Res. 2008, 163, 633-644. [CrossRef]

77. Pettit, G.R.; Ye, Q.; Herald, D.L.; Hogan, F.; Pettit, R.K. Antineoplastic agents. 573. isolation and structure of papilistatin from the papilionid butterfly Byasa polyeuctes termessa. J Nat Prod. 2010, 26, 164-166. [CrossRef]

78. Mansson, M.; Gram, L.; Larsen, T.O. Production of bioactive secondary metabolites by marine Vibrionaceae. Mar. Drugs 2011, 9, 1440-1468. [CrossRef] [PubMed]

79. Jang, K.H.; Nam, S.J.; Locke, J.B.; Kauffman, C.A.; Beatty, D.S.; Paul, L.A.; Fenical, W. Anthracimycin, a potent anthrax antibiotic from a marine-derived actinomycete. Angew. Chem. Int. Ed. 2013, 52, 7822-7824. [CrossRef] [PubMed]

80. Hammami, R.; Zouhir, A.; Ben Hamida, J.; Fliss, I. BACTIBASE: A new web-accessible database for bacteriocin characterization. BMC Microbiol. 2007, 7, 89. [CrossRef] [PubMed]

81. De Jong, A.; van Heel, A.J.; Kok, J.; Kuipers, O.P. BAGEL2: Mining for bacteriocins in genomic data. Nucleic Acids Res. 2010, 38, W647-W651. [CrossRef] [PubMed]

82. Van Heel, A.J.; de Jong, A.; Montalban-Lopez, M.; Kok, J.; Kuipers, O.P. BAGEL3: Automated identification of genes encoding bacteriocins and (non-)bactericidal posttranslationally modified peptides. Nucleic Acids Res. 2013, 41, W448-W453. [CrossRef] [PubMed]

83. Wang, G.; Li, X.; Wang, Z. APD3: the antimicrobial peptide database as a tool for research and education. Nucleic Acids Res. 2015, 44, D1087-D1093. [CrossRef] [PubMed]

84. Brahmachary, M.; Krishnan, S.P.; Koh, J.L.; Khan, A.M.; Seah, S.H.; Tan, T.W.; Brusic, V.; Bajic, V.B. ANTIMIC: A database of antimicrobial sequences. Nucleic Acids Res. 2004, 32, D586-D589. [CrossRef] [PubMed]

85. Wang, C.K.; Kaas, Q.; Chiche, L.; Craik, D.J. CyBase: A database of cyclic protein sequences and structures, with applications in protein discovery and engineering. Nucleic Acids Res. 2007, 36, D206-D210. [CrossRef] [PubMed]

86. Wang, J.; Yin, T.; Xiao, X.; He, D.; Xue, Z.; Jiang, X.; Wang, Y. StraPep: A structure database of bioactive peptides. Database 2018, 2018, bay038. [CrossRef] [PubMed]

87. Bibi, F.; Faheem, M.; Azhar, E.I.; Yasir, M.; Alvi, S.A.; Kamal, M.A.; Ullah, I.; Naseer, M.I. Bacteria From Marine Sponges: A Source of New Drugs. Curr. Drug Metab. 2017, 18, 11-15. [CrossRef]

88. Ruocco, N.; Costantini, S.; Palumbo, F.; Costantini, M. Marine Sponges and Bacteria as Challenging Sources of Enzyme Inhibitors for Pharmacological Applications. Mar. Drugs 2017, 15, 173. [CrossRef] [PubMed]

89. Dias, T.; Gaudêncio, S.P.; Pereira, F. A Computer-Driven Approach to Discover Natural Product Leads for Methicillin-Resistant Staphylococcus aureus Infection therapy. Mar. Drugs 2018, 17, 16. [CrossRef] [PubMed]

90. Giordano, D.; Coppola, D.; Russo, R.; Verde, C.; Denaro, R.; Giuliano, L.; Lauro, F.M.; di Prisco, G. Marine Microbial Secondary Metabolites: Pathways, Evolution and Physiological Roles. Adv. Microb. Physiol. 2015, 66, 357-428. [CrossRef] [PubMed]

91. Amin, S.A.; Parker, M.S.; Armbrust, E.V. Interactions between diatoms and bacteria. Microbiol. Mol. Biol. Rev. 2012, 76, 667-684. [CrossRef] [PubMed]

92. Wang, Z.; Wang, X.; Wang, J. Recent Advances in Antibacterial and Antiendotoxic Peptides or Proteins from MarineResources. Mar. Drugs 2018, 16, 57. [CrossRef]

93. Pereira, F.; Aires-de-Sousa, J. Computational Methodologies in the Exploration of Marine Natural Product Leads. Mar. Drugs 2018, 16, 236. [CrossRef] [PubMed] 
94. Ruiz-Torres, V.; Encinar, J.A.; Herranz-López, M.; Pérez-Sánchez, A.; Galiano, V.; Barrajón-Catalán, E.; Micol, V. An Updated Review on Marine Anticancer Compounds: The Use of Virtual Screening for the Discovery of Small-Molecule Cancer Drugs. Molecules 2017, 22, 1037. [CrossRef]

95. Nguyen, T.V.; Alfaro, A.C.; Young, T.; Green, S.; Zarate, E.; Merien, F. Itaconic acid inhibits growth of a pathogenic marine Vibrio strain: A metabolomics approach. Sci. Rep. 2019, 9, 5937. [CrossRef]

(C) 2019 by the authors. Licensee MDPI, Basel, Switzerland. This article is an open access article distributed under the terms and conditions of the Creative Commons Attribution (CC BY) license (http://creativecommons.org/licenses/by/4.0/). 